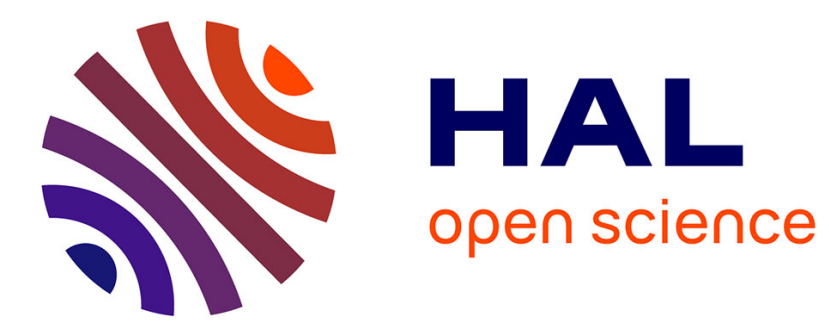

\title{
Assessment of periglacial response to increased runoff: An Arctic hydrosystem bears witness
}

Eric Bernard, Jean Friedt, Sophie Schiavone, Florian Tolle, Madeleine Griselin

\section{To cite this version:}

Eric Bernard, Jean Friedt, Sophie Schiavone, Florian Tolle, Madeleine Griselin. Assessment of periglacial response to increased runoff: An Arctic hydrosystem bears witness. Land Degradation and Development, 2018, 29 (10), pp.3709 - 3720. 10.1002/ldr.3099 . hal-02399275

\section{HAL Id: hal-02399275 \\ https://hal.science/hal-02399275}

Submitted on 9 Dec 2019

HAL is a multi-disciplinary open access archive for the deposit and dissemination of scientific research documents, whether they are published or not. The documents may come from teaching and research institutions in France or abroad, or from public or private research centers.
L'archive ouverte pluridisciplinaire HAL, est destinée au dépôt et à la diffusion de documents scientifiques de niveau recherche, publiés ou non, émanant des établissements d'enseignement et de recherche français ou étrangers, des laboratoires publics ou privés. 


\title{
Assessment of periglacial response to increased runoff. An Arctic hydrosystem as a witness.
}

\author{
Eric Bernard \\ CNRS, \\ Université de Franche Comté, \\ Besançon, \\ France, \\ eric.bernard@univ-fcomte.fr \\ Jean Michel Friedt \\ Sophie Schiavone \\ Florian Tolle \\ Madeleine Griselin
}

June 15, 2018

\begin{abstract}
In the general context of global warming, the cryosphere appears as an environment which exhibit a strong sensitivity to climate variations. Overall glacier systems are now known to be reliable indicators of climate trends. Although glacier dynamics are subject to international monitoring networks, periglacial environments are much less enlightened. However, these newly deglaciated areas get wider since glaciers are retreating, and their dynamics become increasingly significant.

The observed increased water fluxes, rising temperatures and precipitations, permafrost melting and reduced cold periods, induce a combined control on modifications of the glacier and periglacial dynamics. Such consequences are also visible on the landscape, hinting at an adaptation of the environment to the climatic forcing.

The work carried out focuses on Austre Lovénbreen area, a small $10 \mathrm{~km}^{2}$ glacier basin (Svalbard, $78.87^{\circ} \mathrm{N}, 12.15^{\circ} \mathrm{E}$, west coast of Spitsbergen) exhibiting typical arctic glacial retreat trends. Its geomorphological characteristics as well as its observatory status make it an appropriate control area.

Our investigations are based on a combination of classical on-site snow, ice and geomorphological measurements, combined with innovative methods using aerial photography (e.g. from Unmanned Aerial System) and digital photogrammetric image processing. Such data currently complement classical remote sensing methods (satellite imagery), providing both improved resolution and high temporal repeatability. Indeed, short acquisition time and flexibility allow measurements within very short time intervals, a requirement when short events are significant in the whole system evolution: the speed at which climatic change related events occur requires such fine grained spatial and temporal monitoring.

This work highlights an increase of sediment transfer during the last decade which ties in with the increasing liquid precipitation as well as a temperature rising trend. The newly deglaciated area, particularly at the glacier front, is in constant and fast reshaping, which is quantifiable from one year to another, assessing the increase of periglacial landscape modification.
\end{abstract}

\section{INTRODUCTION}

The cryosphere, especially in Arctic environment, is a core topic of accelerated response to climate change. Today, glaciers are indisputable and reliable indicators to better understand climate trend and enabling 
to quantify the response of cold environments to climate change (Lefauconnier et al. 1993 ; Radić et al. 2013 ; Kohler et al. 2007a ; Hagen and Liestøl 1990). In this specific context, glacier dynamics are widely investigated and subject of international monitoring networks (Carr and Coleman 2007 ; Paul 2010). However, periglacial environments are much less enlightened and monitored. These landforms are highly sensitive to freeze-thaw processes in the ground and weakened by temperatures shifts (Bennett et al. 2013). Thus, they also may be considered as relevant indicators of environmental response to climatic conditions (Lukas et al. 2005 and Evans 2009). These newly deglaciated areas expand continuously since glacial retreat increases. Consequently, new processes are observed (Rippin, Pomfret, and King 2015 ; Tonkin et al. 2016) inducing new dynamics, mainly on melting (Rutter et al. 2011), proglacial reshaping (Lyså and Lønne 2001) and sediment transfer (Midgley et al. 2013 ; Rippin, Pomfret, and King 2015). Formerly dominated by permafrost freezing/thawing cycles, these environments slowly switch to new post-glacial systems where the role of torrential hydrology significantly increases as mentionned by Barr and Lovell 2014.

Several studies (Marlin et al. 2017 ; Nowak and Hodson 2013) assess that water fluxes and material motion are increasing due to the accelerated and extended thawing season, simultaneously with increased liquid precipitations, rising temperatures and permafrost melting. This climatic trend affects the morphological dynamics in the moraine, and increased sediment transport from the glacier to the shore (Bourriquen et al. 2016). All induce a combined control on modifications of the glacier and periglacial dynamics. Such consequences are also visible on the landscape, hinting at an adaptation of the environment to the climatic forcing as highlighted by Bernard et al. 2016 and Tonkin et al. 2016. According to James and Robson 2014, topographic change detection is a suitable method in geomorphology for linking processes and forcings to rates and patterns of erosion and deposition. This is supported by the fact that, in the current context of climate shift, cold regions are more specifically witnessing these impacts through periglacial environment response. As was described by Immerzeel et al. 2014 and Tonkin et al. 2016, this method requires repeated surveys of the area of interest. On this basis, Cook 2017 has demonstrated that considering changes at an accurate spatio-temporal scale, the use of Unmanned Aerial System (UAS) provides an easy way to obtain high resolution data with high accuracy.

Our investigations are based on a combination of classical on-site geomorphological observations and measurements (Terrain Analysis and landform recognition, tangential photographs), combined with increasingly used methods using aerial photography (e.g. from UAS) and digital photogrammetric image processing. Such data currently complement classical remote sensing methods (satellite imagery), providing improved resolution and high temporal repeatability. Indeed, short acquisition time and flexibility allow measurements within very short time intervals. As identified in (Bernard et al. 2016), it is a requirement when geomorphological processes are increasingly affected by so-called warm events (e.g. rain on snow events, floods, sudden re-warming described by Nowak and Hodson 2013 and Eckerstorfer and Christiansen 2011b). Thus, the speed at which climatic change related events occur requires such accurate spatial and temporal monitoring in order to quantify their impacts (Westermann et al. 2011 ; Parajka et al. 2012).

Most of geomorphological studies, especially on paraglacial environments and its evolutionary dynamics, deal with long term time-series (Kirkbride and Winkler 2012 ; Røthe et al. 2015 ; Evans 2009 ; Rachlewicz 2010) and generally at a global scale (Baldi et al. 2008 ; Hagen et al. 2003). Obviously, this choice allows to highlight significant changes over several decades, and describes how newly deglaciated environments adapt under the impact of climate shift (Rutter et al. 2011). Quantification of potential annual changes (or at any rate considering a local spatio-temporal scale), e.g. using photogrammetry or LiDAR for geomorphological modeling is considerably less common (Friedt et al. 2011). However, several previous works focused on proglacial moraine side ends dynamics (Midgley et al. 2013, Tonkin et al. 2016, Tonkin et al. 2014), and highlighted the response of ice cored moraines to current climate trends. Recent dynamics over newly deglaciated areas, because of its novelty, are less highlighted.

The aim of this research deals with short-term climatic events which have been identified as typical response mechanisms of contemporary rapid climate variations (Dyurgerov and Meier 2000, Marlin et al. 2017, Nowak and Hodson 2013 and Oerlemans 2005). More precisely, the goal is here to investigate dynamics at the interface between the glacier front and the proglacial moraine. Over this contact zone, significant materiel movements (Bennett et al. 1996) occur ever more frequently. Sudden meteorological shifts trigger floods and massive outflows, which generate sediment transfer from source to sink (Bennett et al. 2013). These phenomenon result in significant morphological and topographical changes. Thus, understanding the transformation of modern proglacial moraines is a major topic for a proper interpre- 
tation of how glacial system adapt to current climate shift impacts. Previous work (Bernard et al. 2016) has demonstrated that in only a few days, a flood is likely to generate exceptional landscape transformations such as water streams, moraine morphology or even collapsing. This work is build upon the highlights of recent periglacial environments evolution. Here, the following questions are investigated: (1) the magnitude of geomorphological dynamics at the front of the glacier, including spatial dynamics and transfer of sediments and (2) the possibility of detecting the volume of sediments transfer and its spatial dynamics.

\section{Geographichl Settings}

This work was carried out over the basin of Austre Lovénbreen, located on the west coast of Spitsbergen (high-Arctic), on Brøggerhalvøya $\left(79^{\circ} \mathrm{N}, 12^{\circ} \mathrm{E}\right)$. This $10.58 \mathrm{~km}^{2}$ basin consists in a small land-terminating valley and polythermal glacier (Saintenoy et al. 2013) surrounded by a periglacial environment divided in two main areas: a rugged alpine terrain upstream and a wide proglacial moraine downstream.

The glacier itself represents today no more than $4.3 \mathrm{~km}^{2}$, and $3.8 \mathrm{~km}$ in length (from South to North) while it was around $5 \mathrm{~km}$ long at its Neoglacial maximum. Previous studies (Marlin et al. 2017 ; Bernard et al. 2016) have highlighted a continuous glacial retreat dynamics considering that Austre Lovénbreen mass balance is almost always negative since 2007 (which corresponds to the beginning of continuous monitoring). Indeed, according to Marlin et al. 2017 ; Bennett et al. 1996 and historical imagery analysis, the glacier front has receded by more than $1 \mathrm{~km}$ since the Little Ice Age maximum extent (end of the nineteenth century), in the same way as similar glaciers from the surrounding area (Kohler et al. 2007a). Continuous glacial retreat observed on Austre Lovénbreen is associated with climate shift impacts on negative mass balances recorded occasionally since 1969 but yearly since 2007 to present. Friedt et al. 2011 and Marlin et al. 2017 mapped the evolution of the glacier volume since the LIA (Little Ice Age) and its fronts position between 1948 and 2016 as well as its surface decrease: showing an average length change of $-16 \mathrm{~m} \cdot \mathrm{a}^{-1}$ ( $-19 \mathrm{~m} \cdot \mathrm{a}^{-1}$ along the central flow line). Thus, consequently of the measured glacier surface area decreased, the surface of the whole moraine almost constantly increases. In addition to this, a substantial proglacial material relocation is observed since lots of sediments are carried by the glacier, consequently to slopes high instability (Lukas et al. 2005). This means that the proglacial moraine is today in a constant reshaping, and results in massive material movements.

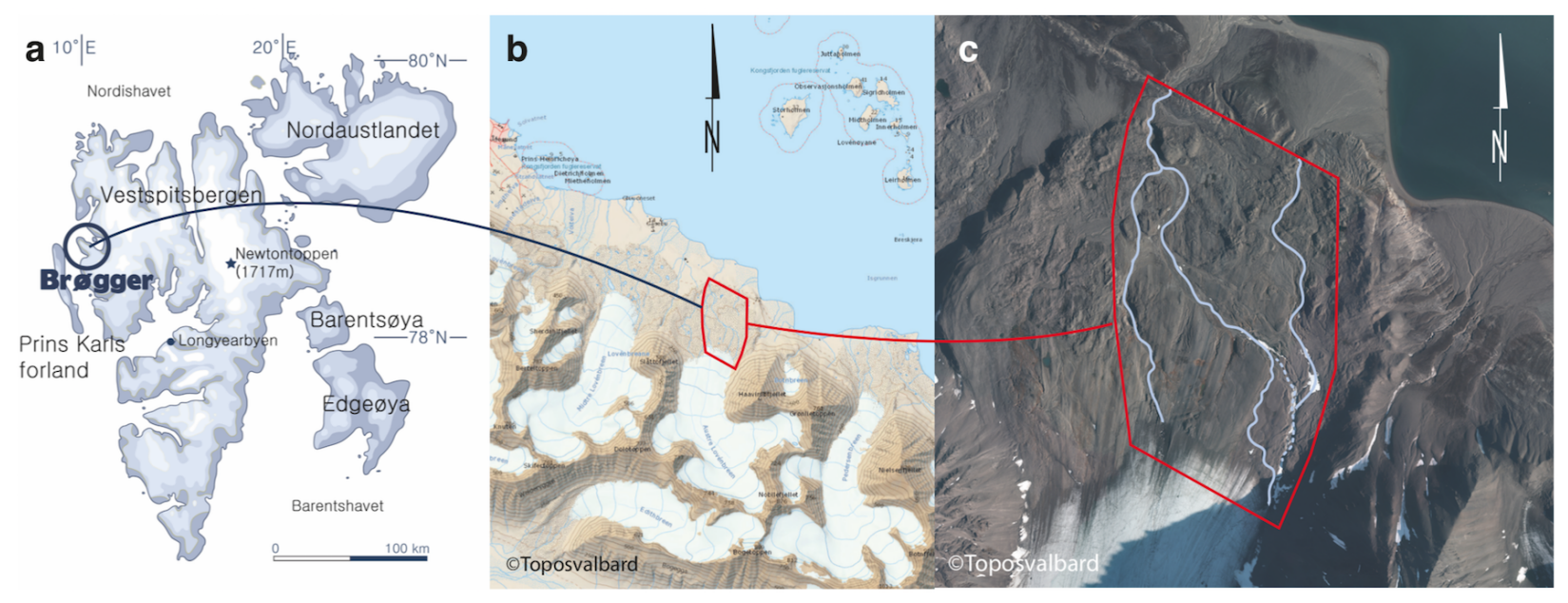

Figure 1: (a) shows the location of the fieldwork on the west coast of Spitsbergen. (b) highlights the environment of the glacial basin with actual glacier limits. It is located at the interface sea-land and at the interface of the metamorphic/sedimentary faces of the Brøgger peninsula. (c) focuses on the proglacial moraine, representing today $2.5 \mathrm{~km}^{2}$. It shows the actual hydrologic network and the old stream on the dashed line. The large yellow dotted line is the actual front while the thin white dotted line is the maximum front extend in 1948 . 
Today, the moraine complex could be divided in a large external morainic scree, described by Hambrey 1991 and Tonkin et al. 2016 as a large arcuate lateral-frontal moraine which is breached at two locations by the main contemporary glacio-fluvial outlets (the main streams cross a compact limestone ridge, marking the extremity of the catchment upstream from the coast). This external morainic arc is identified as hummocky moraine (Bennett and Evans 2012) and represents parts where dynamics are less pronounced or, at least, where processes unfold inside the materials through ice core melting. This typical external topography delineates the proglacial moraine which consists in a large sedimentary complex exhibiting successive retreats of the glacier (Bernard et al. 2016). A particular shape at the interface with the glacier snout is easily identifiable due to the fast retreat during the last decade (Kohler et al. 2007b). Indeed, the interface glacier front-moraine as well as the buffer zones along watercourses were shown as very sensitive to morphological changes (Røthe et al. 2015, Hambrey and Glasser 2012, Cook et al. 2007). These areas can undergo significant changes, depending on the amount of climatic stress events, such as floods or significant liquid precipitation (Irvine-Fynn et al. 2011, Brönnimann, Ewen, and Luterbacher 2008). These morphological adaptations are clearly visible in the landscape from one year to another (Fig. 2).
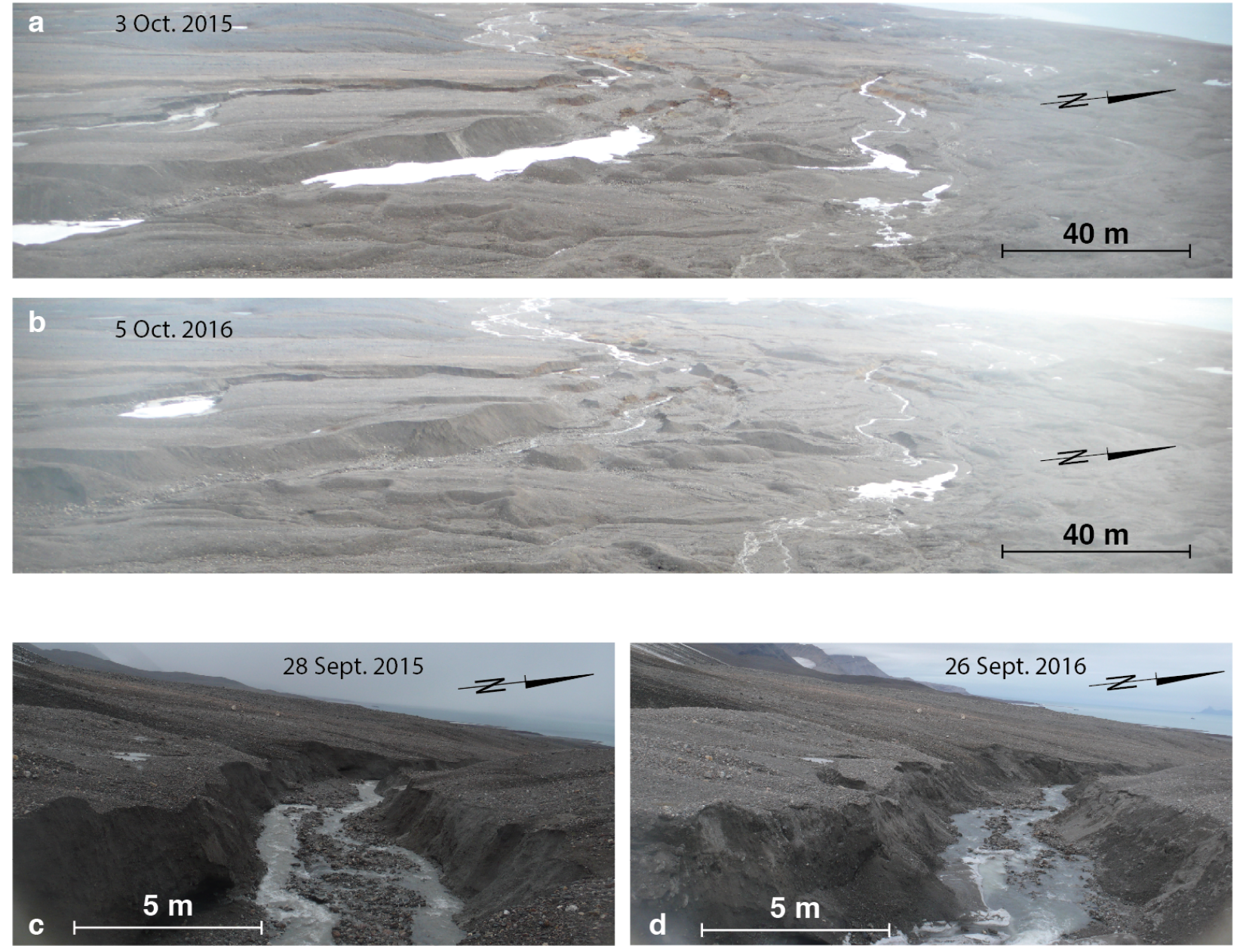

Figure 2: The figure highlights how fast morphological changes could be. Here are two examples of river systems evolutions from one year to another. (a) and (b) is an overview of the active area, dominated by stong outflows. (c) and (d) is a focus on the main outlet of the glacier, at the interface with the glacier tongue.

Despite the very northerly location of Brøggerhalvøya, it experiences a warmer climate as assumed 
at such latitudes due to the influence of the warm North Atlantic current terminus. Ny-Ålesund climate stations recorded a mean annual temperature of $-6.3^{\circ} \mathrm{C}$ on the 1961 to 1990 period and $-5.2^{\circ} \mathrm{C}$ from 1981 to 2010, typical of a polar oceanic climate (Brönnimann, Ewen, and Luterbacher 2008, Eckerstorfer and Christiansen 2011a). Most important in the context of this paper is the increase of liquid precipitations, regardless the season (Westermann et al. 2011, Gardner and Sharp 2009).This is a major phenomenon that Bakke et al. 2013, Wright 2005 and Rippin, Pomfret, and King 2015 highlighted as a key parameter to runoff processes and a major contribution to meltwater dynamics. Consequences on proglacial moraine response is significant since these phenomenon are considered as an increasing trend.

This paper maintains the focus on the interface between the glacier front, the contact moraine area and the main water system to provide surface morphological data that could be used at different time scale, to highlight accelerating rate of proglacial moraine movements.

\section{MATERIALS AND METHODS}

\subsection{Reference dataset and terrain observations}

A dataset provided by Norsk Polarinstitutt (NPI) was used as spatial references for this work. The first dataset consists in a DEM acquired in 1995 with a $5 \mathrm{~m}$ resolution. It covers the area of both Midtre Lovénbreen and Austre Lovénbreen. The second consists of an orthophoto of the whole peninsula (16 cm pixel size, available as a WMTS service at http://geodata.npolar.no/arcgis/rest/services/ Basisdata/NP_Ortofoto_Svalbard_WMTS_25833/MapServer/WMTS/1.0.0/WMTSCapabilities.xml) and its associated DEM (5 m resolution, available at https://publicdatasets.data.npolar.no/kartdata/) both acquired in 2010. Both spatial resolution and coverage are well suited for data correction. In order to compare these data, all DEMs were cropped to fit the area of interest including the moraine and surrounding areas.

Aerial photographs as well as remote sensing data do not provide a sufficient level of informations and details. It needs to be complemented by field observations and measurements based on classical methods of Terrain Analysis (TA) as described by Schillaci, Braun, and Kropáček 2015. The workflow leans on ground-based photographs and topographical survey (dGPS) in order to identify specific landforms and their geomorphic features.

Climatic data were obtained through $\mathrm{Ny}$-Ålesund weather station, $8 \mathrm{~m}$ a.s.l.. As the weather station is $6 \mathrm{~km}$ west from Austre Lovénbreen basin, a patch based on orography and assessed by the litterature (Braithwaite 1966) was applied to fit with the on-site measured tempreatures. Indeed, this extrapolation was compare and validated with our own in situ recorded data. Concerning the precipitation, no rain gauge is available on the glacial basin itself either. Data were also extracted from the Ny-Ålesund weather station, and corrected according to an altitudinal gradient of 1.5, as used in previous works (Marlin et al. 2017 and Braithwaite 2008). These data (Fig. 3) has to be united with available images that has been used in this work.

\subsection{Data acquisition}

Observing geomorphological evolutions of the moraine on timescales ranging from days to years and with sub-meter spatial resolution over an area of a few $\mathrm{km}^{2}$ is adressed using a small commercial Unmanned Aerial System (UAS) - DJI Phantom3 Advanced (Fig. 4). We used the non-native dedicated software Altizure (www.altizure.com) to set both flight plans and flight parameters. This software, running on digital tablet, allows to set each flight parameter. This method improves both acquisition efficiency (e.g. flight time/area coverage) and data quality, improving the resulting photogrammetric process. The UAS was pre-programmed to fly at an altitude of $110 \mathrm{~m}$ above ground level (AGL) giving a ground sampling distance (GSD) of $2 \mathrm{~cm}$. Each area of interest was pre-defined on an aerial image, and directly implemented through the software interface. Photos are acquired along a regular pattern with $85 \%$ overlap along the trajectory and $65 \%$ overlap from one path to the next in the rectangular raster scan of the area being observed. The typical horizontal speed of $8 \mathrm{~m} \cdot \mathrm{s}^{-1}$ and flight autonomy of about 15 minutes allows for covering an area of $1.58 \mathrm{~km}^{2}$ during each flight considering the flight altitude. Images were acquired with an angular aperture of the camera of $81 \times 66^{\circ}\left(94^{\circ}\right.$ diagonal, oriented at nadir), yielding a surface coverage of each photo of $188 \times 143 \mathrm{~m}^{2}$ with a ground resolution of $4000 \times 3000 \mathrm{px}$. 


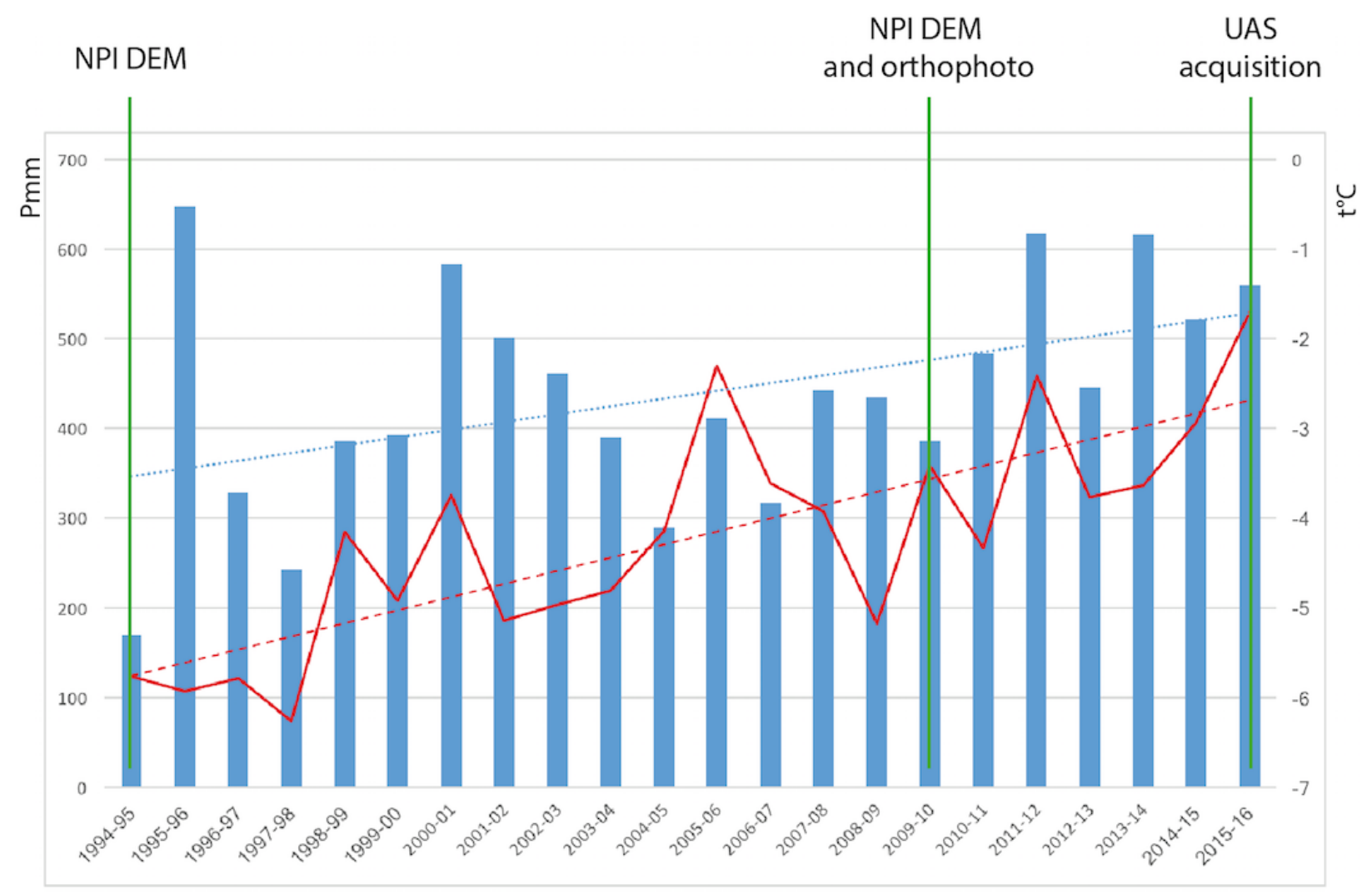

Figure 3: Meteorological data on the considered period: increase of mean air temperatures (MAT) as well as increase of precipitation are highlighted by this chart. Each date at which images were acquired is plotted on the graph, giving the time-scale of the studied evolutions. Both dashed lines represent the trend for temperatures and precipitation over the considered period.

The camera used was the 12 megapixel serial optic closing at f/2.8. General parameters (ISO sensitivity, shutter speed and focal aperture) have been set depending on the light conditions as well as the ground nature (e.g. bare stones, ice, ground type, fresh snow/deep snow). In other words, the automatic setting mode was avoided to address widely changing lighting conditions as met in the low lying sun geometry of the Spring and Fall time measurements and the shutter-priority mode was selected. Most of the time, a 1/450 s shutter speed was used. In Autumn, the low-lying sun involves a low contrast. Thus, the goal was to strike a balance between brightness and sharpeness. Furthermore, flights were undertaken in a glacial environment, meaning that the local aerology is controled by catabatic wind activity. Consequently, the programmed speed may have varied to adapt the UAS stabilization: this means that forward overlap will also have varied through each flight path.

In the context of this work, Ground Control Points (GCPs) are a major issue since deploying markers is challenging in Autumn due to short day light and harsh weather conditions.

Thus the whole workflow for data acquisition used by Bernard et al. 2016, was improved and adapted. This includes the use of both natural and artificial GCPs for accurately positioning the orthophoto and Digital Elevation Model (DEM), a mandatory requirement when assessing difference of DEM (Difference of DEM, DoD) to investigate small geomorphological evolutions over the short time period of a few years. The Figure 4 shows the distribution of the two types of GCPs that were used.

The distribution of GCPs is strongly restricted by the harsh arctic environment. Considering this point and according to the conclusions of Tonkin et al. 2016 about the best compromise of how many GCPs are needed, the network was organised over: 

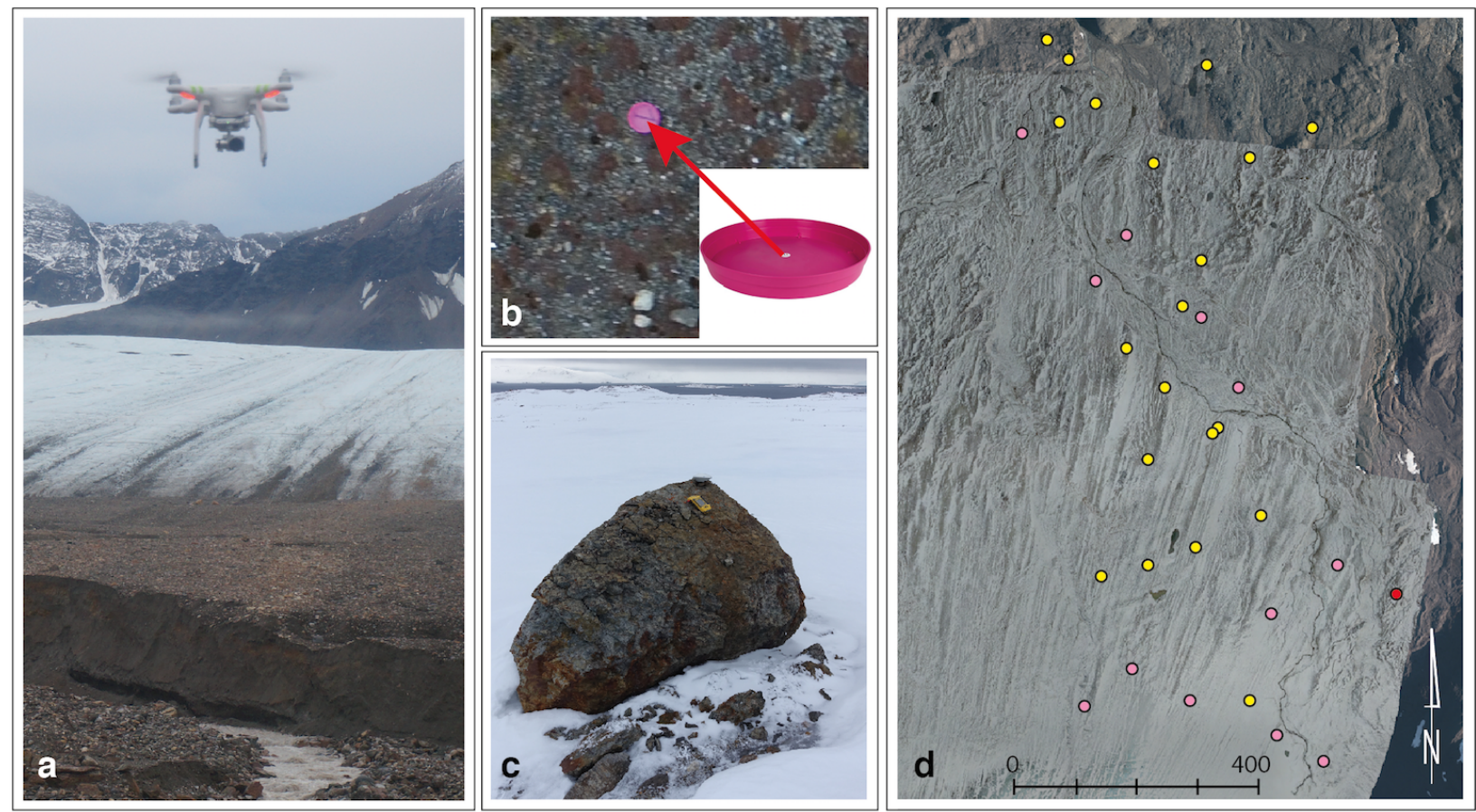

Figure 4: (a) shows the DJI Phantom used for data acquisition, in its original settings. The overall easy handling of this UAS is a major asset in harsh environment. (b) highlights one type of the used Ground Control Points (GCPs). Despite the bright colour, it is not always easy to point on images. In order to workaround this, some erratic boulders were also used as a GCPs (c). They are seldom buried by snow, and thus easy to point on images.(d) represents the distribution of GCPs, distinguishing the blocs in yellow and the plastic saucers in pink. The red dot is the main UAS take-off/landing place which was also used as a GCP reference.

- the deployment of 12 artificial GCPs reference points, represented by pink plastic gardening saucers (as shown on Fig. 4 (d)) which were screwed on the moraine ;

- 20 "easy-to-point" boulders, of a size bigger than $1 \mathrm{~m}^{3}$ and distributed over the moraine that have completed the network.

The plastic GCPs were placed on flat or mid-slope position and preferentially on convex area. The boulders were measured as it is, since we obviously did not choose the distribution as well as their position. The coordinates of artificial GCPs were recorded together with flight sessions using a Trimble Geo XH and Zephir antenna set up. A second measurements session was carried out specifically for the boulders. This step took no more than 2 consecutive days to record every GCP coordinates.

Locating with sub-decimeter on the pictures the location where the GPS antenna was positioned on the boulder while recording is a challenging task, since no edge or corner is clearly identifiable on the aerial photos. On the contrary, each plastic GCP was precisely measured on its center. The postprocessing with differential correction of GCPs was undertaken through the dedicated software (GPS Pathfinder Office). Despite these on-site problems, the dataset was corrected, using the $\mathrm{Ny}$-Ålesund reference station RINEX files, providing centimetre positional and height accuracies around $15 \mathrm{~cm}$ for $98 \%$ of the markers.

\subsection{Data processing and analysis}

In this work, we used and compared both orthophotos and DEMs: the former provides the information on spatial dynamics while the latter allows for quantifying geomorphological changes. From the original set 
of 2233 images, 1758 images were selected for the model reconstruction, using the Agisoft Photoscan 1.4.0 software package. Images were visually and manually assessed for quality and blurry images (or images with a bad framing) were removed prior to processing. Image processing followed the recommended procedure outlined by Agisoft (2013), well described by Verhoeven 2010, taken over by Dietrich 2016 in geomorphological contexts and widely described by Westoby et al. 2012 and Colomina and Molina 2014. The protocol we used was also assessed in several works carried out in cold and/or arctic environments Bernard et al. 2016, Whitehead, Moorman, and Wainstein 2014 or Ryan et al. 2015. Photoscan follows a common Structure from Motion (SfM) and multiview stereopsis (MVS) workflow starting with image feature identification and feature matching. In this work, the number of photos to process was quite important. We made the choice to undertake data processing through a computing center. This reduces significantly the calculation time (from more than 300 hours to less than 25 hours per step) with an accuracy set to "high" position in Photoscan. The initial bundle adjustement results in a sparse 3D point cloud of the terrain (45 millions points). After GCP adjustements and model improvement, the recomputed bundle adjustment gave a new 3D model, from which a DEM was generated by gridding the 3D model based on a given cartographic projection (WGS84 UTM 33N) and cell size (10 cm). From one acquisition to another, differences (color, contrast, lighting) could appear on overlapping photos dataset. This issue was fixed by using the basic "colors correction" tool given by Photoscan and described by Westoby et al. 2012 and Harwin, Lucieer, and Osborn 2015. Overlaped zones were blended and corrected, and the original photos were projected on the 3D surface to produce an orthophoto mosaic of the whole area.

An assessment of the accuracy in easting $(\mathrm{X})$, northing $(\mathrm{Y})$, and height $(\mathrm{Z})$ was carried out for both orthophoto and DEM. Ten of the plastic GCPs were excluded from the georeferencing step in the SfM process, and were identified afterward on the orthophoto. The coordinates of the pink saucers centroids were pointed on the image and compared with the corresponding surveyed GPS coordinates. The geometric accuracy assessment, based on our GCPs network, gave an overall root mean squared error (RMSE) of 0.064 which is, according to the specific conditions, consistant with the litterature (Harwin, Lucieer, and Osborn 2015, Niethammer et al. 2012).

As it was already done in similar works (Girod et al. 2016 specifically on a similar area), the difference of DEM (DoD) method was applied by subtracting spatially coincident raster grid cells from each other. This step allows to assess and quantify morphological changes between different periods of data acquisition. In view of these very different dataset (e.g. photogrammetry vs aerial images from remote sensing), areas with assumed stable terrain (i.e. mainly external moraine) were taken as a reference while comparing DEM to each others. The resulting standard deviation of $1.96 \mathrm{~m}$ was concluded as an acceptable margin of error in a context of geomorphological changes detection in a glacial basin.

Thus, in a final step, we calculated the magnitude of elevation discrepancies between surfaces interpolated from each survey, focusing on areas of interest (e.g. the ones observed on the field as most unstable). Two main areas have been given priority, according to field observations: the front of the glacier on the one hand, and the main glacier outlet crossing the proglacial moraine on the other.

\section{Results}

\subsection{Morphological evidence of surfaces changes}

Two phenomena trigger significant geomorphological changes. Firstly, obvious morphological changes are mainly due to the significant glacier retreat, which can be observed in the 6 years gap between the reference dataset and our recent measurements (2010 to 2016). During such a short time interval, the front of the glacier has retreated by nearly $110 \mathrm{~m}$ along the central flowline and more than $35 \mathrm{~m}$ on both banks. This results in a wide newly deglaciated area where permafrost is not yet well installed. This dynamic has a significant impact because the new proglacial area is mainly composed of soft and non-cohesive sediments, which are unstable and hence extremely sensitive to strong outflows.

Knowing that water runoff always takes the shortest and quickest path, the most significant obstacles are avoided and/or circumvented. That was the case while an ice plug spanning the width of the outflow proglacial valley forced the runoff on the right bank. With the glacier retreat, new ways were much simpler, even by incision into the non-cohesive sediments rather than the ice (Fig.5). This new channel, of which a third was newly eroded, was $808 \mathrm{~m}$ long while the abandoned one was $680 \mathrm{~m}$ at its maximum (2010). 

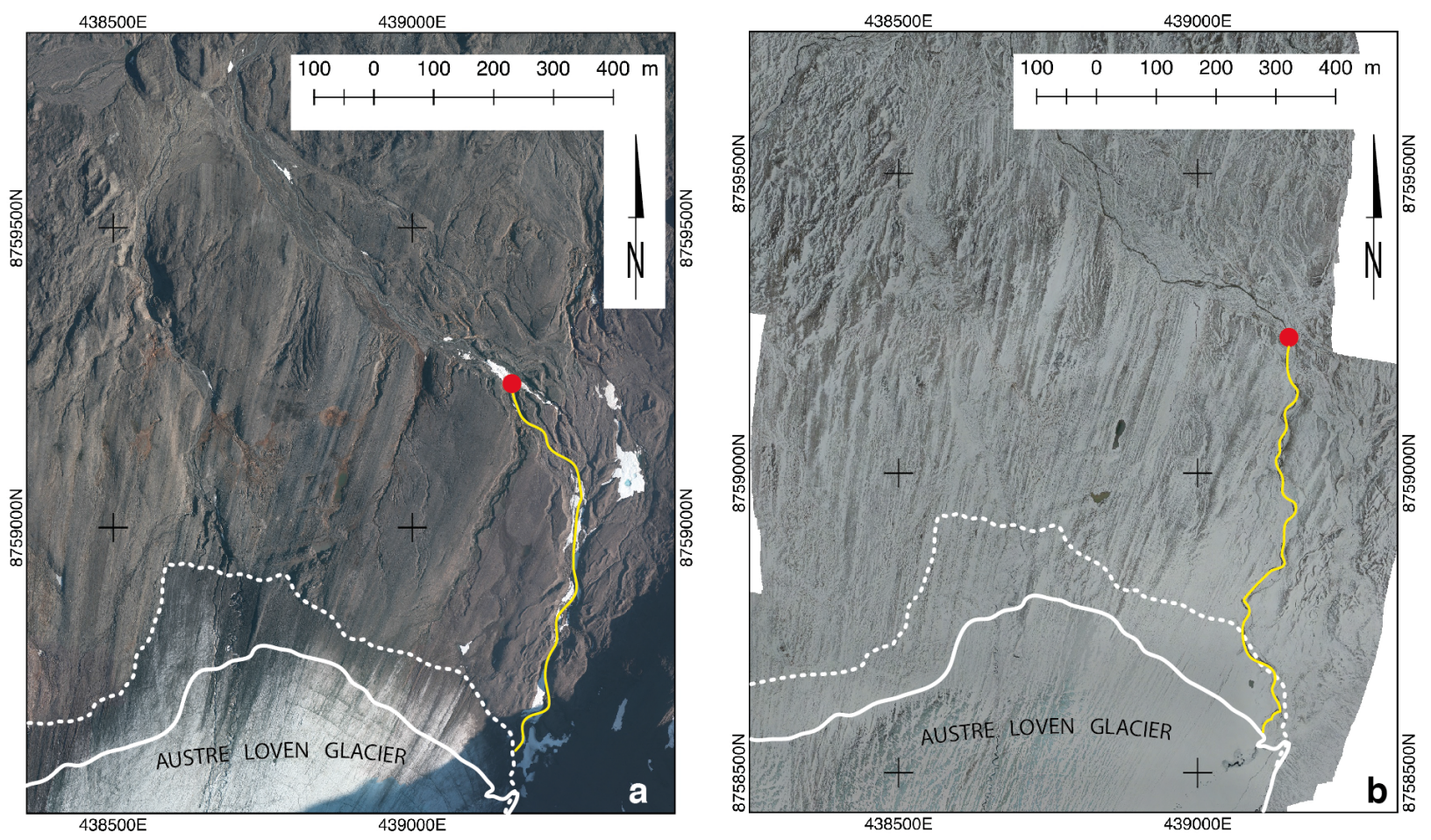

Figure 5: (a) shows the streamflow as it was until 2010 on the Eastern bank of the moraine (aeriel picture from NPI). (b) exhibits the new main streamflow following a different channel (aerial image assembled from UAS acquisition, 2016). This new redrawing of the river bed is mostly due to the glacier recession, opening new outflows possibilities. On both images, the doted line represents the glacier front in 2010 while the white line is the glacier front as it was in 2016. The red dot is the point of confluence, from which the river bed has not changed.

This point leads to the second phenomenon, which is the increase of runoff as highlighted by Marlin et al. 2017. A significant amount of water, due to the increase of melting, global outflows, and an extended period of melting leads to an increase of water flows which has strong impacts on proglacial moraine reshaping. This directly affects the global morphology of the proglacial moraine, which is yet unstable and very sensitive to extend discharges. As a result, we can observe that 3 main channels were used for the main outflows. These proglacial valleys are clearly identifiable on the 2016-1995 DEM difference. Due to the asymmetrical shape of the glacier, most of the outflows appear on the right bank, which explains the proximity of these channels, all on the Eastern side. Despite the moraine, the rivers followed a slightly straight route. This could be explained both by the processes of sediments collapsing (i.e. due to their low cohesion) and by the high flow energy of the streams, especially in melting period.

One of the hypothesis concerned the transfer of sediment through the main outlet. The high-energy flows and their increase observed and measured during the last 10 years (Marlin et al. 2017) suggest that a massive amount of sediments should be on the braid plain. However, no quantitative assessment has been provided since no significant surface change is detected in this area. The DoD shows that the old moraine, located just upstream the braid plain of the main river is stable and does not move significantly. On the opposite, the front of the glacier area shows changes as a significant part of the tong melted, releasing a new morainic area. This newly deglaciated area consists mainly of non-cohesive sediment, which is in movement as soon as under- and supraglacial discharge occur.

Either way, the most significant change is truly the new river bed that had appeared suddenly. The comparison between the 2 ortho-images shows that the structure of the thalweg is the same. That means that according to the increase of the discharge, the river braiding is not so obvious, witnessing the strongness of outflows during thawing and flood events. 


\subsection{Difference of DEM and volumes moved}

To assess the quantity of moved sediments, we made several DEM differences in order to have a basis for comparison, as the initial assumption was based on the short time period impact of short violent event on the proglacial moraine.

On the 2010-1995 DEM difference, the main visible changes concern Austre Lovénbreen retreat as well as the right bank of the proglacial moraine which caves in several points (Fig.6). The most noteworthy values are attributed to the disappearance of icings. This is assessed by aerial photo control. The residual icing holes are characterized by a depth of between 1.9 et $3.3 \mathrm{~m}$. Thus, it is no longer a transfer of sediments but rather morphological changes induced by the absence of these structures. Nevertheless, we can evaluate an amount of less than $3,000 \mathrm{~m}^{3}$ of transfered icings. It is not significant in view of the $11,175 \mathrm{~m}^{2}$ eroded in the channel area. After all, the main outlet, combining both subglacial and supra-glacial flows is characterised by a wide and deep proglacial valley which was constantly deepened but mostly widened over the 1995-2010 period (in average, from 20 meters wide in 1995 to more than 34 meters wide in 2010). This could be explained by the continuing decline of icings, but mostly because of the high-level of water fluxes during the last decade (an increase of runoff highlighted by Sobota 2016). These dynamics result in a dissymmetry at the glacier front interface morphology, along with a subsidence phenomenon. Indeed, the right-most side moraine area collapsed as a whole.

However, this statement (i.e. the strong influence of river discharge) must be nuanced, since each year, we can observe several lateral moraine mass movements, which feed the sediment fluxes. These dynamics would imply an accumulation of material, but actually the DoD shows a different process, as mentioned before. Actually, and compared to other areas, the proglacial valley itself does not change a lot over the 1995-2010 period. Rather, we can assess that the slopes of the lateral moraine significantly collapse. Massive sediment movements could be measured, with volumes moved approaching $20,000 \mathrm{~m}^{3}$ between 1995 and 2010, largely exceeded what is evacuated only from the river bed. The cartographic analysis does not prove that it happened in one event, but field observations during the last 10 years tend to think that this event happened within a very short period. The outflows increase combined with the absence of significant sedimentary deposition suggest that all volumes of sediments (lateral moraine landslides and river sediment transfer) have mostly been carried downstream by the flow of the water.

Besides these geomrophological processes, the gradual disappearance of the glacier front is highly visible and is clearly a trigger of downstream dynamics. The strongest values reach around $-28 \mathrm{~m}$ of height loss, which is consistent with glacier mass balance measurements (Marlin et al. 2017 and Friedt et al. 2011). This wide vacuum created by the melting is actually a new area where both outflows and runoff are in reconfiguration.

The comparison between 2010 and 2016 shows an overall stability of the moraine with few spatial changes. The end result is that it is easier to detect visible changes (and through them new processes) in just 6 years. While the significant glacial decrease is well highlighted both in volume and in spatial extent, three changed areas are identifiable (Fig.7). Box (a) on Fig. 6 corresponds to the main outlet of supraglacial runoff. The deepening reaches here more than $10 \mathrm{~m}$ (11.7 m max.) which indicates that supraglacial runoff are strong enough to significantlfy modify the initial valley which was incised into a limestone ridge. This ridge is today completely eroded and reduced to a bunch of stones with an heterogeneous granulometry, integrated to debris-fall processes, initiated by frost shattering. As a result, a steep river valley concentrates the supraglacial runoff which follows afterward some existent linear features, either as depressions or as more indistinct positive relief lineations with rather unremarkable embankments.

Box (b) in Fig. 7 is meant to be the area of interest which has triggered this work. It is a focus on the new channel, which concentrates most of the runoff. The combined effects of the increase of melting, the proglacial moraine degradation and the unstable upper moraine (located at the bottom of the external slopes, mostly on the right bank) favors fast and powerful erosion of the river bed. One of the main consequences is the self-perpetuating process. This relies on the fact that the more runoff, the more erosion, the stronger and faster flows become. Still, these phenomena imply a positive feedback loop whose consequences are an accelerating rate of sediment erosion.

Box (c) in Fig. 7 includes the area of abandoned channels. Remember that 2010 was the landmark year when the main outlet changed its stream to another channel. From there, the DoD between 2010 and 2016 highlights significant holes, fully due to the disappearance of remaining icings. Indeed, no more flows passes through these old channels, except runoff coming from the slopes and the steep external 


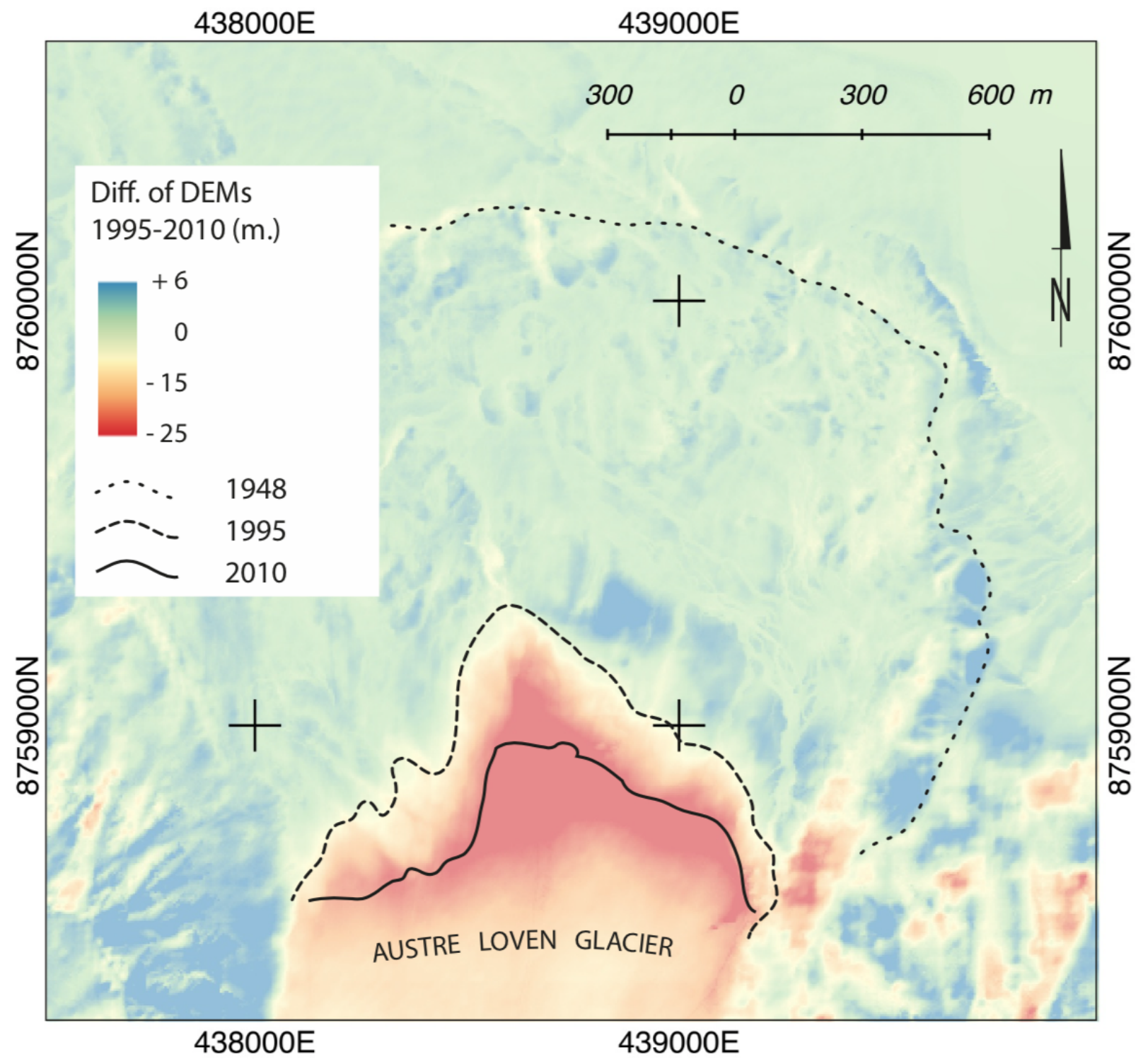

Figure 6: 15 year DEM difference between 2010 and 1995. Both DEMs are given with a $5 \mathrm{~m}$ resolution as provided by NPI. Major changes occured on the areas freed by the glacier retreat (dashed to solid line), but also on the right bank of the moraine, where the bulk of outflows are located.

moraine. But their proportion is rather weak. In that respect, we can evaluate the thickness of these icings. The biggest may reach as deep as $6 \mathrm{~m}$, assuming that the icing is in contact with the bottom (which is not always the case).

In less than 6 years, the median incissing proglacial river into channel bedrock is $1.35 \mathrm{~m}$ per year, as well as an average increase of $3 \mathrm{~m}$ in width (width average from $14 \mathrm{~m}$ to $17 \mathrm{~m}$ ). In order to upgrade the analysis, a field assessment has to be carried out. Nevertheless, in the absence of such field measurement, we notice that the fluvial erosion is more important in width than in depth. This demonstrates how strong the runoff are and how fast they erode the banks, which are unstable and easy erodable. The result is a massive transfer of sediments of approximately $29,500 \mathrm{~m}^{3}$, corresponding to a $16,412 \mathrm{~m}^{2}$ channel surface. Note that even by considering a longer river bed due to the glacial retreat, the overall surface is much 


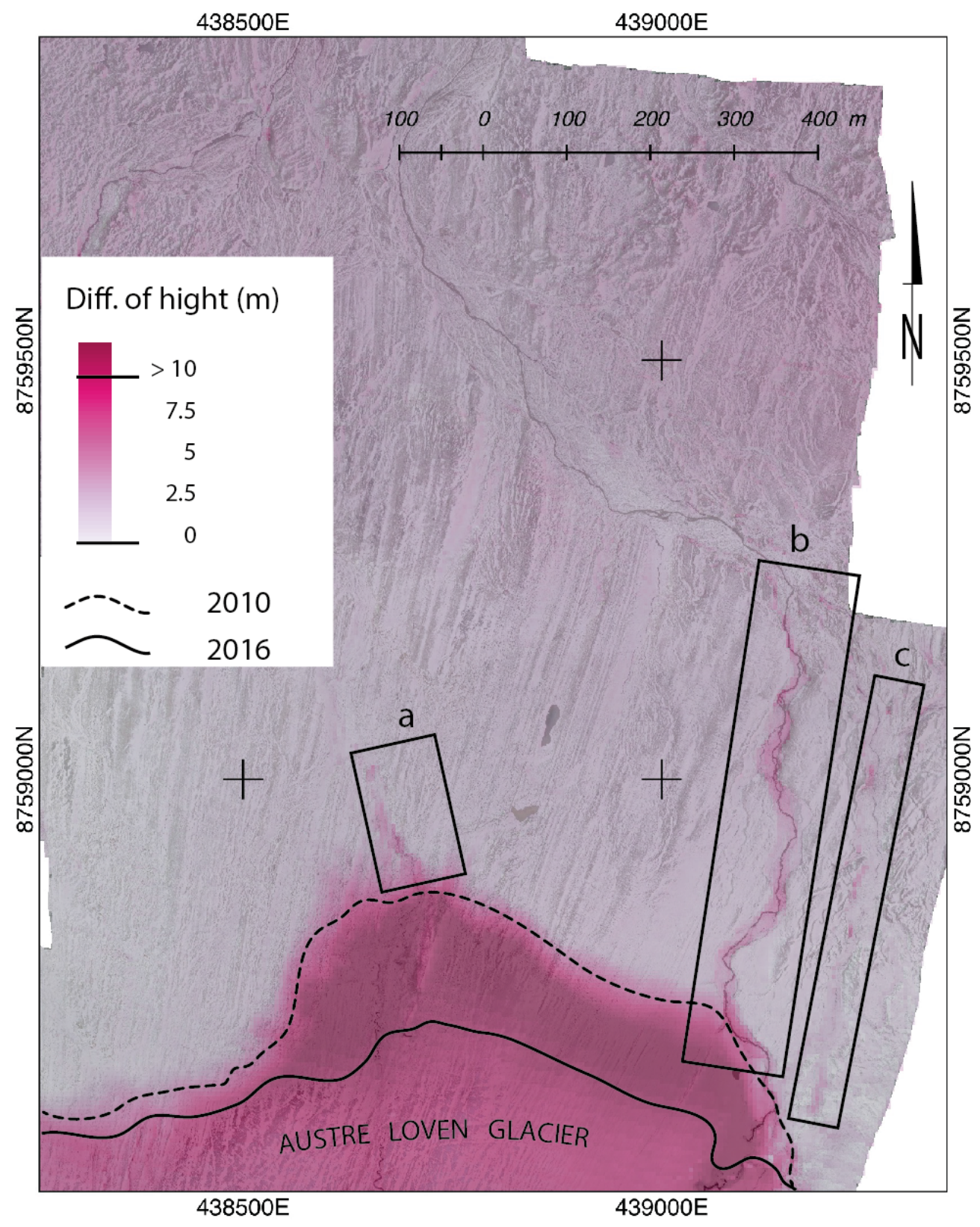

Figure 7: The difference of DEMs between 2010 and 2016 highlights 3 areas where significant mophological changes could be observed. (a) is a main outlet of supra glacial runoff. (b) corresponds to the digging of new channels while (c) is the disappearance of old icing areas. To have a better perception, a transparency was applied to the DoD which is superimposed on the 2016 orthophoto.

more wider than the 1995-2010 period. Furthermore, this significant amount of sediments is toppled over the catchment, combined with sediments from tundra erosion (in the foreland of the glacier marginal zone) as mentionned by Weckwerth and Sobota 2017. These processes are thus actively involved in the coastal dynamics such as progradation described by Bourriquen et al. 2016. If we compare the 2 periods of observations, this results that over 6 years, as much as three times more sediments were dragged by river/glacier discharge than in 15 years. This calculation does not take into account the volumes coming 
from the landslides as their dynamics are somewhat uncertain. Thus, the computation was only based on the channels evolution.

\section{Discussion}

We processed aerial photographies and derived DEMs at a short time interval, which is a rarely used method in periglacial geomorphology but allows for GIS analysis of a high-scale spatial distribution of induced dynamics.

Moraines in the high-Arctic glacial environment are understood to be highly vulnerable to thermoerosion and mass movement facilitated by fluvial undercutting. This can result in high rates of landform transformation (Ewertowski and Tomczyk 2015). This is particularly true in the specific active band we discussed, according to the glacier/proglacial moraine interface. It seems that both combined effects of so called warm events (i.e. sudden and short temperature increase with liquid precipitation), triggering sudden and significant melting, have an impact on moraine re-shaping and sediment transport. This is mainly due to its flash flood processes giving an nearly immediate influx of liquid water on not yet stabilized sediments.

In addition, it is admitted that the proglacial moraine is under the influence of the accumulation of sediments in front of glaciers, which occurs via supraglacial transport or by transfer of debris from subglacial positions into supra or englacial positions along shear planes or debris bands. However, sediments cannot accumulate significantly under the influence of strong runoffs. Most of these sediments are discharged further into the moraine or even reach the sandur area and/or the coastline (as there is no signifcant sediment accumulation in the flood plains of the main outlets).

In the light of this work, it is possible to assess that the increase of runoff both in terms of quantity and period is a major trigger of proglacial moraine reshaping in a short time period.

We argue that geomorphological studies based on commonly used methods and periods (over a few decades) of observation underestimate the influence of short, violent climate events, especially with regard to the reshaping of landforms. It appears that the succession of warm and rainy events have a fast impact on geomorphological processes. It is clear that the pattern of glacier retreat and melting influences the disintegration of the moraine complex, sediment distribution and the formation of frontal moraines.

Finally, the East-West imbalance of the proglacial moraine is directly due to the asymmetry of the glacier, itself constrained by the bedrock. The concentation of much of the water fluxes on a small area (since the glacier front gets smaller) explains that the flow energy is one of the main mechanism of morphological reshaping. Supraglacial drainage has to be considered as an important process for melting of glacier ice in high-arctic systems. As it was observed (Lønne 2007), we also have a similar conclusion that coalescing meltwater channels will lead to a higher capability for sediment transport. On the basis of the DoD 1995-2010, the altitude increasing in some parts of the proglacial area (marginal zone of Austre Lovénbreen, especially in the area located close to the 2010 glacier limits) of $+5 \mathrm{~m}$ could be explained considering the sediments redeposition due to gravity-flows and moraine relief levelling. These sediments are actually out of the main outflows and are therefore not evacuated outside the morainic curve. Furthermore, melting of buried ice has to be taken into account, since these dynamics could be an accelerating process (or at least a trigger) to proglacial moraine disintegration. This can cause several stages of topographic reversal, but in this work the step of repeated resedimentation of debris could not be observed since the runoff are strong enough to evacuate sediment deposits. Sediment gravity-flows, as it is somtimes observed, cannot make resedimentation but are directly evacuated into the streamflow. The disintegration processes of the proglacial moraine (at the extended interface with the glacier tong) does not result in the levelling of the moraine relief and morphology as expected. In the case of Austre Lovénbreen, it results in indistinct features as the only evidence of former glacier front positions. Concerning the recent past abandonned channels, as observed by Lyså and Lønne 2001, they are becoming an indication of a former glaciation, meltwater channels or sediments related to a source no longer in existence at the present time.

\section{Conclusion}

We have applied remote sensing, on-site aerial image acquisition and field observations and measurments for assessing the geomorphological evolution of the newly deglaciated areas in an Artctic proglacial 
moraine environment. Short term evolutions are observed in the active areas recently freed by the glacier retreat: in the case of Austre Lovenbréen, the supraglacial stream was forced by an ice plug to find a new path and moved through the brittle newly deglaciated area which offered least resistance. Beyond the qualitative analysis, Digital Elevation Models (DEM) allow for a quantitative analysis of the volume of material moved, including sediments displaced by the streams. We observe an increase associated both to increased liquid precipitations and increased water fluxes.

Further investigations will aim at reducing the uncertainty on successive DEM generation to lower the error bar on the volume measurement and hence reduce the time interval between successive analysis to address the impact of short, violent events on the geomorphological evolution of the moraine. Indeed, while landscape transformations are clearly visible over short periods, the quantitative results are not so clear when computing data from one year to another. A yearly time period of observations is needed to highlight the fast proglacial environment response to climate shift, as observed on the field. Extreme climatic events seem to be largely one of the main trigger of the accelerating rate of erosion processes: their consequences take part in the general trends. But on the other hand, one single event cannot trigger massive changes: it is rather a combination of processes that explains best the observed changes in the global morphology evolution of the proglacial moraine. Thus, it is concluded that an intensive monitoring of this key area is needed to asses the proportion of each mechanism in the proglacial moraine reshaping dynamics.

\section{ACKNOWLEDGEMENT}

This study was supported by a Franche Comté county grant. We acknowledge IPEV for logistics support in Svalbard as well as J.-P. Culas at Photocoptère S.A.S (Besançon, France) for technical support on UAS maintenance and regulations.

\section{References}

Bakke, Jostein et al. (2013). "Numerical analyses of a multi-proxy data set from a distal glacierfed lake, Sørsendalsvatn, western Norway". In: Quaternary Science Reviews 73, pp. 182-195. ISSN: 02773791. DOI: 10.1016/j.quascirev.2013.05.003. URL: http://dx .doi .org/10 . 1016/j.quascirev.2013.05.003.

Baldi, P. et al. (2008). "Kinematics of a landslide derived from archival photogrammetry and GPS data". In: Geomorphology 102.3-4, pp. 435-444. ISSN: 0169555X. DOI: 10.1016/j.geomorph. 2008.04.027. URL: http://dx.doi.org/10.1016/j.geomorph.2008.04.027.

Barr, Iestyn D. and Harold Lovell (2014). "A review of topographic controls on moraine distribution". In: Geomorphology 226, pp. 44-64. ISSN: 0169555X. DOI: 10.1016/j.geomorph. 2014. 07.030. URL: http://dx.doi.org/10.1016/j.geomorph.2014.07.030.

Bennett, G. L. et al. (2013). "Patterns and controls of sediment production, transfer and yield in the Illgraben". In: Geomorphology 188, pp. 68-82. ISSN: 0169555X. DOI: 10 . $1016 / \mathrm{j}$. geomorph.2012.11.029. URL: http://dx.doi.org/10.1016/j.geomorph.2012.11.029.

Bennett, Georgina L. and David J A Evans (2012). "Glacier retreat and landform production on an overdeepened glacier foreland: The debris-charged glacial landsystem at Kvíárjökull, Iceland". In: Earth Surface Processes and Landforms 37.15, pp. 1584-1602. ISSN: 01979337. DOI: 10.1002 /esp. 3259 .

Bennett, M R et al. (1996). "Moraine Development at the High-Arctic Valley Glacier Pedersenbreen, Svalbard". In: Geografiska Annaler. Series A, Physical Geography 78.4, pp. 209-222. ISSN: 04353676, 14680459. DOI: 10.2307 /521041. URL: http: //www . jstor . org/stable/ 521041.

Bernard, É et al. (2016). "Using a small COTS UAV to quantify moraine dynamics induced by climate shift in Arctic environments". In: International Journal of Remote Sensing 0.0, pp. 1-15. ISSN: 0143-1161. DOI: 10 . 1080/01431161 . 2016 . 1249310. uRL: http : //Www . 
tandfonline.com/action/journalInformation? journalCode=tres $20\{\backslash \%\} 0$ Ahttp: //dx . doi.org/10.1080/01431161.2016.1249310.

Bourriquen, Marine et al. (2016). "Coastal evolution and sedimentary mobility of Brøgger Peninsula, northwest Spitsbergen". In: Polar Biology, pp. 1-10. ISSN: 07224060. DOI: 10.1007/ s00300-016-1930-1.

Braithwaite, Roger J (1966). "Degree-days". In: pp. 1-7.

Braithwaite, Roger J. (2008). "Temperature and precipitation climate at the equilibrium-line altitude of glaciers expressed by the degree-day factor for melting snow". In: Journal of Glaciology 54.186, pp. 437-444. ISSN: 00221430. DOI: 10.3189/002214308785836968. URL: http : / / openurl . ingenta. com/ content / xref ? genre=article $\{\backslash \&\}$ issn=0022-1430\{ $\backslash \&$ \} volume $=54\{\backslash \&\}$ issue $=186\{\backslash \&\}$ spage $=437$.

Brönnimann, S, T Ewen, and J Luterbacher (2008). "A focus on climate during the past 100 years". In: pp. 1-25. URL: http://link . springer . com/chapter/10 .1007/978-1-4020$6766-2\left\{\backslash_{-}\right\} 1$.

Carr, Simon and Christopher Coleman (2007). "An improved technique for the reconstruction of former glacier mass-balance and dynamics". In: Geomorphology 92.1-2, pp. 76-90. ISSN: 0169555X. DOI: 10.1016/j .geomorph.2007.02.008. URL: http://linkinghub.elsevier . com/retrieve/pii/S0169555X07000724.

Colomina, I. and P. Molina (2014). "Unmanned aerial systems for photogrammetry and remote sensing: A review". In: ISPRS Journal of Photogrammetry and Remote Sensing 92, pp. 7997. ISSN: 09242716. DOI: 10.1016/j.isprsjprs. 2014.02.013. URL: http://linkinghub . elsevier.com/retrieve/pii/S0924271614000501.

Cook, Kristen L. (2017). "An evaluation of the effectiveness of low-cost UAVs and structure from motion for geomorphic change detection". In: Geomorphology 278, pp. 195-208. ISSN: 0169555X. DOI: 10.1016/j.geomorph.2016.11.009. URL: http://dx.doi.org/10.1016/j. geomorph.2016.11.009.

Cook, Simon J. et al. (2007). "North West". In: North West Geography 7.1.

Dietrich, James T. (2016). "Riverscape mapping with helicopter-based Structure-from-Motion photogrammetry". In: Geomorphology 252, pp. 144-157. ISSN: 0169555X. DOI: $10.1016 / \mathrm{j}$. geomorph.2015.05.008. URL: http://dx.doi.org/10.1016/j.geomorph.2015.05.008.

Dyurgerov, M B and M F Meier (2000). "Twentieth century climate change: evidence from small glaciers." In: Proceedings of the National Academy of Sciences of the United States of America 97.4, pp. 1406-11. ISSN: 0027-8424. URL: http://www .pubmedcentral .nih .gov/ articlerender.fcgi?artid=26446\{\\&\}tool=pmcentrez $\{\backslash \&\}$ rendertype=abstract.

Eckerstorfer, M. and H.H. Christiansen (2011a). "Relating meteorological variables to the natural slab avalanche regime in High Arctic Svalbard". In: Cold Regions Science and Technology 69.2-3, pp. 184-193. ISSN: 0165232X. DOI: 10.1016/j . coldregions . 2011 .08 . 008. URL: http://linkinghub.elsevier.com/retrieve/pii/S0165232X11001637.

Eckerstorfer, Markus and Hanne H. Christiansen (2011b). "The "High Arctic Maritime Snow Climate" in Central Svalbard". In: Arctic, Antarctic, and Alpine Research 43.1, pp. 11-21. ISSN: 1523-0430. DOI: 10.1657/1938-4246-43.1.11. URL: http://www . bioone.org/doi/ abs $/ 10.1657 / 1938-4246-43.1 .11$.

Evans, David J A (2009). "Controlled moraines: origins, characteristics and palaeoglaciological implications". In: Quaternary Science Reviews 28.3-4, pp. 183-208. ISSN: 02773791. DOI: 10. 1016/j.quascirev. 2008.10.024. URL: http://dx.doi.org/10.1016/j .quascirev. 2008. 10.024 .

Ewertowski, Marek W. and Aleksandra M. Tomczyk (2015). "Quantification of the ice-cored moraines' short-term dynamics in the high-Arctic glaciers Ebbabreen and Ragnarbreen, Petuniabukta, Svalbard". In: Geomorphology 234, pp. 211-227. ISSN: 0169555X. DOI: 10.1016/j . geomorph.2015.01.023. URL: http://dx.doi.org/10.1016/j.geomorph.2015.01.023. 
Friedt, J-M. et al. (2011). "Assessing the relevance of digital elevation models to evaluate glacier mass balance: application to Austre Lovénbreen (Spitsbergen, 79N)". English. In: Polar Record 48.01, pp. 2-10. ISSN: 0032-2474. DOI: 10.1017/S0032247411000465. URL: http://journals. cambridge.org/abstract $\left\{\backslash \_\right\}$S0032247411000465.

Gardner, Alex S. and Martin Sharp (2009). "Sensitivity of net mass-balance estimates to nearsurface temperature lapse rates when employing the degree-day method to estimate glacier melt". In: Annals of Glaciology 50.50, pp. 80-86. ISSN: 02603055. DOI: 10.3189/172756409787769663. URL: http : / / openurl . ingenta . com / content / xref ? genre $=\operatorname{article}\{\backslash \&\}$ issn $=0260-$ $3055\{\backslash \&\}$ volume $=50\{\backslash \&\}$ issue $=50\{\backslash \&\}$ spage $=80$.

Girod, Luc et al. (2016). "Terrain changes from images acquired on opportunistic flights by SFM photogrammetry". In: The Cryosphere Discussions October, pp. 1-22. ISSN: 1994-0440. DOI: 10.5194/tc-2016-228. URL: http://www.the-cryosphere-discuss.net/tc-2016-228/.

Hagen, JO and Olav Liestøl (1990). "Long-term glacier mass-balance investigations in Svalbard, 1950-88". In: Annals of Glaciology. URL: http://adsabs . harvard. edu/abs/1990AnGla. .14 . .1020http : / / www . igsoc . org / annals . old/14/igs $\left\{\backslash_{-}\right\}$annals $\left\{\backslash \_\right\}$vol14\{ _ \}year1990\{\_\}pg102-106.pdf.

Hagen, Jon Ove et al. (2003). "Glaciers in Svalbard: mass balance, runoff and freshwater flux". en. In: Polar Research 22.2, pp. 145-159. ISSN: 1751-8369. DOI: $10.1111 / \mathrm{j} .1751-8369$. 2003 . tb00104 . x. URL: http : / / onlinelibrary . wiley . com/doi / 10 . 1111/ j . 1751 8369.2003.tb00104.x/abstract.

Hambrey, Michael J. (1991). "Glaciology". In: Earth-Science Reviews 30.3-4, pp. 326-327. ISSN: 0012-8252. DOI: 10.1016/0012-8252(91)90006-2. URL: http://www.sciencedirect.com/ science/article/pii/0012825291900062.

Hambrey, Michael J. and Neil F. Glasser (2012). "Discriminating glacier thermal and dynamic regimes in the sedimentary record". In: Sedimentary Geology 251-252.0, pp. 1-33. ISSN: 00370738. DOI: $10.1016 / \mathrm{j}$. sedgeo . 2012 .01 .008. URL: http : / www . sciencedirect . com / science/article/pii/S0037073812000152.

Harwin, Steve, Arko Lucieer, and Jon Osborn (2015). "The impact of the calibration method on the accuracy of point clouds derived using unmanned aerial vehicle multi-view stereopsis". In: Remote Sensing 7.9, pp. 11933-11953. ISSN: 20724292. DOI: 10.3390/rs70911933.

Immerzeel, W. W. et al. (2014). "High-resolution monitoring of Himalayan glacier dynamics using unmanned aerial vehicles". In: Remote Sensing of Environment 150, pp. 93-103. ISSN: 00344257. DOI: 10.1016/j.rse.2014.04.025. URL: http://dx.doi.org/10.1016/j.rse. 2014.04 .025$.

Irvine-Fynn, T. D L et al. (2011). "Recent High-Arctic glacial sediment redistribution: A process perspective using airborne lidar". In: Geomorphology 125.1, pp. 27-39. ISSN: 0169555X. DOI: 10.1016/j .geomorph.2010.08.012. URL: http://dx.doi .org/10.1016/j.geomorph . 2010.08 .012 .

James, Mike R. and Stuart Robson (2014). "Mitigating systematic error in topographic models derived from UAV and ground-based image networks". In: Earth Surface Processes and Landforms 39.10, pp. 1413-1420. ISSN: 10969837. DOI: 10.1002/esp.3609.

Kirkbride, M. P. and S. Winkler (2012). "Correlation of Late Quaternary moraines: Impact of climate variability, glacier response, and chronological resolution". In: Quaternary Science Reviews 46, pp. 1-29. ISSN: 02773791. DOI: 10 .1016/j . quascirev . 2012 .04.002. URL: http://dx.doi.org/10.1016/j.quascirev.2012.04.002.

Kohler, J. et al. (2007a). "Acceleration in thinning rate on western Svalbard glaciers". In: Geophysical Research Letters 34.18, p. L18502. ISSN: 0094-8276. DOI: 10 . 1029/2007GL030681. URL: http://doi.wiley.com/10.1029/2007GL030681.

- (2007b). "Acceleration in thinning rate on western Svalbard glaciers". In: Geophysical Research Letters 34.18, p. L18502. ISSN: 0094-8276. DOI: 10 .1029/2007GL030681. URL: http: //doi.wiley.com/10.1029/2007GL030681. 
Lefauconnier, Bernard et al. (1993). "Glacier balance trends in the Kongsfjorden area, western Spitsbergen, Svalbard, in relation to the climate". In: Polar Research 18.2, pp. 307-313.

Lønne, Ida (2007). "Reply to Lukas, S., Nicholson, L.I., Humlum, O. (2006). Comment on L??nne and Lys?? (2005): Deglaciation dynamics following the Little Ice Age on Svalbard: Implications for shaping of landscapes at high latitudes. Geomorphology 72, 300-319". In: Geomorphology 86.1-2, pp. 217-218. ISSN: 0169555X. DOI: 10.1016/j.geomorph.2006.08.003.

Lukas, Sven et al. (2005). "Formation, Meltout Processes and Landscape Alteration of HighArctic Ice-Cored Moraines-Examples From Nordenskiold Land, Central Spitsbergen". In: Polar Geography 29.3, pp. 157-187. ISSN: 1088-937X. DOI: 10.1080/789610198.

Lyså, Astrid and Ida Lønne (2001). "Moraine development at a small High-Arctic valley glacier: Rieperbreen, Svalbard". In: Journal of Quaternary Science 16.6, pp. 519-529. ISSN: 02678179. DOI: $10.1002 /$ jqs. 613.

Marlin, Christelle et al. (2017). "Change in geometry of a high Arctic glacier from 1948 to 2013 (Austre Lovénbreen, Svalbard)". In: Geografiska Annaler: Series A, Physical Geography, pp. 1-24. ISSN: 0435-3676. DOI: 10 . 1080/04353676 . 2017 . 1285203. URL: http: / / www . tandfonline.com/doi/abs/10.1080/04353676.2017.1285203.

Midgley, Nicholas G. et al. (2013). "Origin, evolution and dynamic context of a Neoglacial lateralfrontal moraine at Austre Lovénbreen, Svalbard". In: Geomorphology 198, pp. 96-106. IssN: 0169555X. DOI: 10.1016/j.geomorph.2013.05.017. URL: http://dx.doi.org/10.1016/j . geomorph.2013.05.017.

Niethammer, U. et al. (2012). "UAV-based remote sensing of the Super-Sauze landslide: Evaluation and results". In: Engineering Geology 128, pp. 2-11. ISSN: 00137952. DOI: 10.1016/ j . enggeo . 2011 .03 .012. URL: http : / / linkinghub . elsevier . com/retrieve / pii / S0013795211000755.

Nowak, Aga and Andy Hodson (2013). "Hydrological response of a High-Arctic catchment to changing climate over the past 35 years : a case study of Bayelva watershed, Svalbard". In: Polar Research 1.1, pp. 1-16.

Oerlemans, J (2005). "Extracting a climate signal from 169 glacier records." In: Science (New York, N.Y.) 308.5722, pp. 675-7. ISSN: 1095-9203. DOI: 10.1126/science.1107046. URL: http://www.ncbi.nlm.nih.gov/pubmed/15746388.

Parajka, Juraj et al. (2012). "Potential of time-lapse photography of snow for hydrological purposes at the small catchment scale". In: Hydrological Processes 26.22, pp. 3327-3337. ISSN: 08856087. DOI: 10.1002/hyp.8389. URL: http://doi.wiley.com/10.1002/hyp. 8389.

Paul, F. (2010). "The influence of changes in glacier extent and surface elevation on modeled mass balance". In: The Cryosphere 4.4, pp. 569-581. ISSN: 1994-0424. DOI: 10.5194/tc-4569-2010. URL: http://www. the-cryosphere.net/4/569/2010/.

Rachlewicz, Grzegorz (2010). "Paraglacial Modifications of Glacial Sediments Over Millennial to Decadal Time-Scales in the High Arctic (Billefjorden, Central Spitsbergen, Svalbard)". In: Quaestiones Geographicae 29.3, pp. 59-67. ISSN: 0137-477X. DOI: 10.2478/v10117-0100023-4.

Radić, Valentina et al. (2013). "Regional and global projections of twenty-first century glacier mass changes in response to climate scenarios from global climate models". In: Climate Dynamics 42.1-2, pp. 37-58. ISSN: 0930-7575. DOI: 10.1007/s00382-013-1719-7. URL: http: //link.springer.com/10.1007/s00382-013-1719-7.

Rippin, David M., Andrew Pomfret, and Nigel King (2015). "High resolution mapping of supraglacial drainage pathways reveals link between micro-channel drainage density, surface roughness and surface reflectance". In: Earth Surface Processes and Landforms 40.10, pp. 12791290. ISSN: 10969837. DOI: 10.1002/esp. 3719.

Røthe, Torgeir O. et al. (2015). "Arctic Holocene glacier fluctuations reconstructed from lake sediments at Mitrahalvøya, Spitsbergen". In: Quaternary Science Reviews 109, pp. 111-125. 
ISSN: 02773791. DOI: $10.1016 / \mathrm{j}$. quascirev . 2014.11 .017. URL: http : / / linkinghub . elsevier.com/retrieve/pii/S0277379114004776.

Rutter, Nick et al. (2011). "Hydrology and hydrochemistry of a deglaciating high-Arctic catchment, Svalbard". In: Journal of Hydrology 410.1-2, pp. 39-50. ISSN: 0022-1694. DOI: 10.1016/ j.jhydrol.2011.09.001. URL: http://www.sciencedirect.com/science/article/pii/ S0022169411006226.

Ryan, J. C. et al. (2015). "UAV photogrammetry and structure from motion to assess calving dynamics at Store Glacier, a large outlet draining the Greenland ice sheet". In: Cryosphere 9.1, pp. 1-11. ISSN: 19940424. DOI: 10.5194/tc-9-1-2015.

Saintenoy, Albane et al. (2013). "Deriving ice thickness, glacier volume and bedrock morphology of Austre Lovénbreen (Svalbard) using GPR". In: Near Surface Geophysics 11.2, pp. 253-261. URL: http://nsg.eage.org/publication/publicationdetails/?publication=67422.

Schillaci, Calogero, Andreas Braun, and Jan Kropáček (2015). "2 . 4 . 2 . Terrain analysis and landform recognition". In: Geomorphological techniques. Vol. 2. British Society for Geomorphology, pp. 1-18.

Sobota, Ireneusz (2016). "Icings and their role as an important element of the cryosphere in High Arctic glacier forefields". In: Bulletin of Geography, Physical Geography series 10.10, pp. 8193.

Tonkin, T. N. et al. (2014). "The potential of small unmanned aircraft systems and structurefrom-motion for topographic surveys: A test of emerging integrated approaches at Cwm Idwal, North Wales". In: Geomorphology 226, pp. 35-43. ISSN: 0169555X. DOI: 10.1016/j .geomorph . 2014.07.021. URL: http://dx.doi.org/10.1016/j.geomorph.2014.07.021.

Tonkin, T N et al. (2016). "Geomorphology Ice-cored moraine degradation mapped and quanti fi ed using an unmanned aerial vehicle : A case study from a polythermal glacier in Svalbard". In: Geomorphology 258, pp. 1-10. ISSN: 0169-555X. DOI: 10.1016/j .geomorph.2015.12.019. URL: http://dx.doi.org/10.1016/j.geomorph.2015.12.019.

Verhoeven, Geert (2010). "Book Review - A Field Guide to Geophysics in Archaeology". In: Archaeological Prospection 62.December 2009, pp. 61-62. ISSN: 10752196. DOI: 10.1002/arp.

Weckwerth, Piotr and Ireneusz Sobota (2017). "Morphology and surficial sediments of the Waldemar River confined outwash fan". In: Bulletin of Geography, Physical Geography series 13.13, pp. $61-70$.

Westermann, S. et al. (2011). "Modeling the impact of wintertime rain events on the thermal regime of permafrost". In: The Cryosphere 5.4, pp. 945-959. ISSN: 1994-0424. DOI: 10.5194/ tc-5-945-2011. URL: http://www. the-cryosphere.net/5/945/2011/.

Westoby, M.J. et al. (2012). "Structure-from-Motion' photogrammetry: A low-cost, effective tool for geoscience applications". In: Geomorphology 179, pp. 300-314. ISSN: 0169555X. DOI: 10.1016/j.geomorph.2012.08.021. URL: http://linkinghub.elsevier.com/retrieve/ pii/S0169555X12004217.

Whitehead, Ken, Brian Moorman, and Pablo Wainstein (2014). "Measuring daily surface elevation and velocity variations across a polythermal arctic glacier using ground-based photogrammetry". In: Journal of Glaciology 60.224, pp. 1208-1220. ISSN: 00221430. DOI: 10 . 3189/2014JoG14J080. URL: http: //www.igsoc.org/journal/60/224/j14j080.html.

Wright, Andrew Philip (2005). "The Impact of Meltwater Refreezing on the Mass Balance of a High Arctic Glacier". PhD thesis. Bristol, p. 265. 